$\begin{array}{r}\text { Volume and Issues Obtainable at Center for Sustainability Research and Consultancy } \\ \text { Journal of Business and Social Review in Emerging Economies } \\ \text { ISSN: 2519-089X (E): 2519-0326 } \\ \text { Volume 5: Issue 2 December } 2019 \\ \text { CSRᄃ } \\ \text { Journal homepage: www.publishing.globalcsrc.org/jbsee } \\ \hline\end{array}$

\title{
Entrepreneurship Education, School Culture and Organizational Commitment Amongst High Schools in South Sumatra
}

\author{
${ }^{1}$ Leonis Marchalina, ${ }^{2}$ Parmin \\ ${ }^{1}$ Faculty Member, School of Business and Economics, Universitas Prasetiya Mulya \\ Email: leonis.marchalina@pmbs.ac.id \\ ${ }^{2}$ Head Master, Senior High School Plus 17 Palembang \\ Email: parminsuwito@yahoo.com
}

ARTICLE DETAILS

\section{History}

Revised format: November 2019

AvailableOnline:December2019

\section{Keywords \\ Entrepreneurship Education, \\ Organizational Culture, \\ Organizational Commitment, \\ South Sumatra, Indonesia}

\section{JEL Classification:}

L26, L29,D23,D29

\begin{abstract}
The role of entrepreneurship in the education sector is required in order to achieve innovative institutes through various productive programs. In order to pursue a more developed country, Entrepreneurship Education (EE) is needed to create innovative characteristics and entrepreneurial talents whereby economic growth and employment are stimulated. Unfortunately, the entrepreneurship curriculum was a few to be implemented in South Sumatra. Likewise, this issue caused a lower school culture and also the commitment among the teachers in high school in South Sumatra. This study aims to examine thoroughly the influence of entrepreneurship education towards school culture and organizational commitment in those high schools. This research process involved a quantitative approach, whereby the survey was administered among 314 public school teachers and 329 private school teachers with the use of stratified sampling. A cross-sectional research design was applied, whereby the instruments used are entrepreneurship education, organizational culture, and organizational commitment. Descriptive analysis, correlation, T-test, and multiple regression were used to analyze the data based on the objectives of the study. The results have shown that entrepreneurship education has a significantly positive relationship on school culture and organizational commitment. The positive correlation value illustrates that the higher the entrepreneurship education, the greater the increase in positive culture that will motivate the commitment of teachers in public and private high schools. The findings of this study can also be used by the Ministry of Education to identify the characteristics required by the entrepreneurship qualities, the influence of organizational culture, and the commitment of the organization as a benchmark for planning a better national education in the future.
\end{abstract}

(C) 2019 Center for Sustainability Research and Consultancy Pakistan under a Creative Commons Attribution-NonCommercial-ShareAlike 4.0

Corresponding author's email address: leonis.marchalina@pmbs.ac.id

Recommended citation: Marchalina, L., Parmin. (2019). Entrepreneurship Education, School Culture and Organizational Commitment Amongst High Schools in South Sumatra. Journal of Business and Social Review in Emerging Economies, 5 (2) 263-274

DOI: $10.26710 /$ jbsee.v5i2.811 


\section{Introduction}

Education was a fundamental symbol that can influence the quality of civilization in any nation. A strong education can enable a person to enhance their skills and talents. However, the issues of local education relate to the lack of quality of the education itself (Holle, 2009). Previous research has found that teachers play a crucial role towards addressing these issues. An effective, good-quality teacher is one who has good capabilities based on his/her expertise, has a great personality, commitment, and a good work ethic (Holle, 2009).

In this case, schools need leaders who are creative and able to find innovative solutions to problems. Educators must then understand and learn the entrepreneurship skills required in order for the educators to be more creative. Hasan et al. (2017) asserted that entrepreneurship education plays an important role in stimulating an entrepreneurial spirit among students. It has been proved that the students who participate in workshops related to entrepreneurship tend to establish their own startup companies more often than those who do not (Packham et al., 2010). The teachers are required to support students by nurturing their skills related to entrepreneurship and also to improve their own entrepreneurial skills in order to apply them to education. It was found that a higher level of commitment is significantly related to high organizational performance (Farukh et al., 2017). The teachers who reveal their creative ideas tend to be more committed to their schools. This means that the teachers who are emotionally attached to their schools will undoubtedly express their innovative ideas (Chughtai, 2013; Thomson \& Heron, 2006). Schools seem to need the teachers within that have a vision to achieve the organization's objectives by implementing the productive activities effectively and to encourage and motivate their peers as well. Moreover, some literature has found a correlation between organizational commitment and work behaviors (Ozag, 2006; Powell et al., 2006). When the teachers are committed to their schools, they are more likely to devote innovative ideas for the development of their schools. Although there is limited research discussing the relationship between entrepreneurship education and organizational commitment (Hakimian et al., 2016), the phenomena regarding this topic will be further discussed later. Therefore, this study examines the relationship between entrepreneurship education and organizational commitment to fill the gap.

Another factor that influences the commitment of high school teachers is organizational culture. According to Hopkin (2005), school culture and organizational commitment may lead to the setback of a school's performance, whereas these factors actually play a significant role in determining the success of the school's performance (Nurafifiah, 2016). Because internal stakeholders, including teachers, have highly affected the culture within schools, the culture in the schools will change eventually with their increased commitment. Entrepreneurship education is one of the factors that can transform the educational 
system to become more contemporary. Therefore, entrepreneurship education must be examined further in order to contribute to academics as well as the institution itself.

\section{LITERATURE REVIEW}

\subsection{Entrepreneurship Education}

The success of socio-economic and its sustainability can be determined by the importance of entrepreneurial education (Klinger \& Schündeln, 2011; Matly \& Farashah, 2013). This is because the ability of entrepreneurship education to establish the motivational mindset and to enhance the important skills such as teamwork, critical thinking, and decision-making capabilities (Wilson et al., 2009). Likewise, it involves collaboration of drive, initiative, commitment, perseverance, and creative efforts to display the productive projects through entrepreneurship education (Acs et al., 2008). In addition, other skills such as solving problems abilities, communication skills, and creativity are needed to be a successful entrepreneur. Nevertheless, these skills are mostly acquired through experience, even failure. However, these skills can also be established through entrepreneurship education (Murphy \& Dyrenfurth, 2012).

In developing countries, job vacancies are considered to be an important factor (Brown, 2003). This is because government should ensure the issue of employment opportunities would not be the major national crisis in developing countries for university graduates. Most of the times, educational institutions were failed to establish the market demand and job vacancies for graduates due to the traditional degrees (Brown, 2003). The paradox occur due to the stream of educational institutions that increasing the number of literate citizens in a country cannot balancing the rate of jobless citizens at the same time (Saks \& Ashforth, 2002). Nonetheless, some universities have successfully graduated their graduates into both private and public companies of the economy with various levels of managerial skills. On the other hand, the companies are not obligate to receive the graduates that are not from or drop out from universities. In consequence, the exceptional university graduates are frustrated and become hopeless due to the lack of opportunities because they cannot apply their skills and competencies that they have got from universities in the work field (Okereke \& Okorafor, 2011). As the result of existed output, the imbalance between social and economic occur in the country (Lipton, 1962). Hence, the solution that can be proposed as the only feasible alternatives are entrepreneurship and self-employment. Consistently, many universities in developing countries have included the entrepreneurship courses in their curriculum to deal with the situation (Matlay \& Farashah, 2013). The entrepreneurship education programs were offered in most of universities currently with the hope that the university could produce the university graduates with the competencies that are required to be the entrepreneurs, in which they will choose to be the job inventors rather than the job seekers (Zamberi, 2013). Therefore, this study was prepared to investigate the role of 
entrepreneurial education at the school level in entrepreneurship development.

To be the great entrepreneurs, ones are required the developed skills and competencies. It was proved that the educated entrepreneurs are more important in developing the regional economies rather than the entrepreneurs with a lower level of education academically (Taatila, 2010; Kwiek, 2012). The conventional education is related to the transformation of knowledge and skills. In a contrary, the entrepreneurship education is more associated with the transformation model of the motives and changing attitudes (Hansemark, 1998; Fayolle and Gailly, 2015). However, the literatures related to the effectiveness of teaching method in terms of entrepreneurship courses are very limited (Sexton and Bowman-Upton, 1988; Basant, 2008). There is lack of studies on the relationship bertween organizational commitment and entrepreneurship education with barely no studies pertaining the importance of entrepreneurship education and performance outcomes (Vesper, 1985; Honig, 2004). Therefore, the growing attention related to the universities and other educational institutions regarding the effective entrepreneurship education calls for further conceptual and theoretical development of studies.

\subsection{Organizational Culture}

Deal and Peterson (2004) stated that schools culture determines the patterns of value, beliefs, and tradition. Teachers in schools cooperate together with other stakeholders to exchange cultural aspects to modify the old cultures, to create the new cultures, or to revise some elements that need to be changed. School values within such culture are applied as guidelines for all the internal stakeholders so that they can bring benefit to the schools and create distinction among other organizations.

Deal (1990) mentioned that culture is one of the alternatives or concepts of learning through mind mapping and descriptions and is also supported by the behaviors that affect the human experience. In other words, culture can be defined as the attitudes or actions that have been demonstrated by groups of people in schools who were shaped by trust, togetherness, and shared experiences to influence each other.

In summary, the combination of the values and norms within the schools that belong to all staff members can be used as outcomes from the teachers in order to create a successful culture. Suriansyah (2014) highlighted that the practice of culture or habits that are implemented within the schools will be successful if they are established correctly.

\subsection{Organizational Commitment}

There are two perspectives related to commitment: 1) attitude approach and 2) behavior approach towards 
the organizational commitment (McGee \& Ford, 1987). These researchers stated that attitude approach views commitment as the original condition as well as the effect of the relationship between the school staff members and the school's culture (Oliver, 1990). The staff must have the willingness to devote their energy and effort to the organization as well as a strong desire to consistently improve and perpetuate their expertise within the organization.

On the other hand, the behavioral approach sees commitment as a process in which a person shapes the rationalization of their actions (Oliver, 1990). The theory related to this approach is the side batches theory by Howard Becker (1960). He perceived commitment as a result rather than a collection of rewards such as time, effort, and money, whereby those would be lost and assumed as liabilities if the staff left the organization.

It was illustrated that the teachers who have high commitment to their schools are able to adjust and to adapt as part of their schools compared to the teachers who are not committed to their school (Meyer \& Allen, 1991). In this study, there are three components within the basis of organizational commitment, namely affective commitment, continuous commitment, and normative commitment, which are mentioned within the theory by Allen and Meyer $(1990 ; 1996)$.

Numerous studies have discussed the relationship between organizational culture and commitment among employees (Demir \& Öztürk, 2011; Gülova \& Demirsoy, 2012; Lok \& Crawforld, 1999; Silverthorne, 2004; Yiing \& Ahmad, 2009; Yildirim, Acaray, \& Candan, 2016). Ortega-Parra and Sastre-Castillo (2013) studied the potential differences in culture dimension as perceived by employees, analyzing their value and impact on organizational commitment. Employees play a critical role in affecting the organizational performance toward change. The higher the employees' commitment, the higher the organizational performance (Pinho, Rodrigues, \&Dibb, 2014). Likewise, Akyürek et al. (2013) stated that higher employee commitment results from a strong organizational culture. Organizational culture has been proved to have a strong effect on moderating the organizational commitment (Marchalina et al., 2019). Nonetheless, there are still limited studies that discuss culture within the schools and determine the role of organizational culture on teachers' commitment in their schools. Therefore, this study was conducted to fill the gap.

H1: There is a significant relationship between entrepreneurship education and organizational commitment among high schools in South Sumatra. 
H2: School culture moderates the relationship between entrepreneurship education and organizational commitment among high schools in South Sumatra.

\section{METHODOLOGY}

\subsection{Population and Sampling Techniques}

This study was implemented in the province of South Sumatra, which is part of the country of Indonesia and on one of the large islands of Indonesia. One of the major distinguishing factors of this study is the large number of respondents involved. The research was defined by taking samples from the population and using the questionnaires as the form of data collection for primary tools (Johnson \& Christensen, 2010). Furthermore, this study involved data analysis to test hypotheses and to answer the research questions related to entrepreneurship education towards the organizational commitment and schools' culture.

In implementing this research survey, the researcher found some limitations. Firstly, the respondents chosen were only the teachers of high schools in both public and private schools. Those schools are also accredited from the education authorities in South Sumatra. Moreover, the researcher realized that this research surely cannot described a whole population of high school teachers throughout Indonesia, due to the fact that it only gathers a sample by proportional random sampling from 314 public and 329 private high school teachers in South Sumatra. This is because the researcher believed that the perception of high school teachers toward entrepreneurship education strongly affects the commitment among the teachers toward their schools.

\subsection{Data Collection Methods}

This study used instruments to collect the data in order to obtain the results based on the research objectives. All variables were collected from the instruments that have been measured. The instruments used were entrepreneurship education (Lorz, 2011), organizational commitment (Allen \& Meyer, 1990; Yakoob, 2007), and organizational culture (Maslowski, 2001; Yakoob, 2007; and Kasim, 2015). All research variables use questionnaires with a Likert scale from 1 to 5 . Data will be taken manually or online (online questionnaire), and then random cross checks are carried out in the field towards data.

\subsection{Data Analysis}

In this study, the quantitative analysis will be measured in two stages. Firstly, the reliability test was measured by using mean, intercorrelations, and reliability coefficients. After that, the role of moderating variable was tested by the variation's model. Cronbach's Alpha analysis also was employed to test the reliability. For the hypotheses test, this study used Pearson Correlation analysis (relationship between two 
variables), variance analysis, T-test, and multiple regression analysis, and to test the moderating effect, it used the moderated multiple regression.

\section{RESULTS}

Table 1: Reliability Coefficients of the Main Variables

\begin{tabular}{lll}
\hline Variables & Dimension & $\begin{array}{l}\text { Cronbach Alpha } \\
(\boldsymbol{\alpha})\end{array}$ \\
\hline $\begin{array}{l}\text { Entrepreneurship } \\
\text { education }\end{array}$ & - & 0.953 \\
$\begin{array}{l}\text { School's culture } \\
\begin{array}{l}\text { Organizational } \\
\text { commitment }\end{array}\end{array}$ & - & 0.924 \\
& Affective commitment & 0.938 \\
& Continuous commitment & 0.947 \\
\hline
\end{tabular}

Table 1 above has shown that the reliability and consistency of the questionnaire's instrument based on the results of the study conducted on 700 teachers in the high schools of South Sumatra have found the appropriate Cronbach Alpha value. Meanwhile, the indicator for decision making on the reliability test with a value of 0.8 and above is good. The Cronbach's Alpha 0.6 - 0.7 value is acceptable (Sekaran, 2010). However, Sekaran (2010) states that the minimum Cronbach's Alpha value for reliability is 0.5. Therefore, the overall reliability of all variables if followed by Sekaran (2010) is sufficient. All values of the Cronbach's Alpha for each variable are above 0.5 .

Table 2: The role of Schools' Culture as a moderating variable between entrepreneurship education and organizational commitment

\begin{tabular}{|c|c|c|c|c|c|c|}
\hline $\begin{array}{l}\text { Dependent } \\
\text { Variable }\end{array}$ & Independent Variable & $\begin{array}{l}\text { Adjusted } \\
\mathbf{R}^{2}\end{array}$ & $\mathbf{F}$ & $\begin{array}{l}\text { Parameter } \\
\text { Coefficient }\end{array}$ & $\begin{array}{l}\text { Sig. } \\
\text { F }\end{array}$ & Sig. $t$ \\
\hline $\begin{array}{l}\text { Organizational } \\
\text { Commitment }\end{array}$ & $\begin{array}{l}\text { Entrepreneurship education } \\
\text { School Culture } \\
\text { Entrepreneurship education } \mathrm{x} \\
\text { Organizational culture }\end{array}$ & 0.55 & 13.571 & $\begin{array}{l}0.43 \\
.219 \\
0.86\end{array}$ & .000 & $\begin{array}{l}.270 \\
.000 \\
.025\end{array}$ \\
\hline
\end{tabular}

The output of the SPSS output shows the adjusted R2 values of .055 (Table 2). This means that 5.5\% of the variation in organizational commitment can be explained by variations of independent variable of 
entrepreneurship education and the moderating variable of school's culture, while the balance $(100 \%$ $5.5 \%=94.5 \%$ ) is explained by other reasons beyond the model.

A simultaneous significant test or $F$ test statistic (ANOVA test) yields a value of $F$ of 13,571 with a significant level of .000 . Because the probability is significantly smaller than .05 , regression models can be used to predict organizational commitment or say that entrepreneurship education and school's culture together have an impact on organizational commitment.

Based on the three variables included in the regression, it is clear that entrepreneurship education significantly influences o the organizational commitment. Entrepreneurship education provides a value of coefficient of the parameter .043 with a significance level of .270 , and the variable of school's culture provides a value of coefficient of parameters .219 with a significance level of .000 . The moderator variable, which is the interaction between the entrepreneurship education and the school's culture, is also significant, with a significance value of .025, so the school's culture is a modifier variable. So the result of the analysis shows enough evidence to state that the school's culture plays a role as a modifiable variable in influencing the relationship between entrepreneurship education and organizational commitment among teachers in the SMA South Sumatra Province. This finding supports the established hypothesis.

Table 3: Model Summary of Entrepreneurship Education, School's Culture, and Organizational Commitment

\begin{tabular}{|l|c|r|r|r|}
\hline Model & R & R Square & Adjusted R Square & Std. Error of the Estimate \\
\hline 1 & $.155^{*}$ & .024 & 0.20 & .26732 \\
2 & $.279^{\mathrm{a}}$ & .078 & .074 & .25985 \\
\hline
\end{tabular}

a. Predictors: (Constant), Entrepreneurship Education (EE)

b. Predictors: (Constant), EE, EE*Organizational Culture

c. Dependent Variable: Organizational commitment

The first formula proved that the effect of entrepreneurship education and organizational commitment to change was .024 percent, as indicated by $\mathrm{R}^{2}$. This means that entrepreneurship education explained about $2.4 \%$ (percent) of the variance of organizational commitment. Table 3 shows that the next formula explains the moderating effect of school's culture on the relationship between the entrepreneurship education and organizational commitment. The $\mathrm{R}^{2}$ was .078 , which explains about $7.8 \%$ (percent) of the contingent effect of the school's culture on the correlation between entrepreneurship education and organizational commitment. In summary, the school's culture was proved to have a moderate effect on entrepreneurship education and organizational commitment by having a higher value. 


\section{DISCUSSION}

The findings have shown the effect of entrepreneurship education towards the school's culture and organizational commitment. The data analysis result shows that 463 teachers, comprising 314 public highschool teachers and 329 private high-school teachers, were respondents in this study. Overall, the descriptive analysis findings show that entrepreneurship education, school culture, and organizational commitment in South Sumatra province were high.

The results of the multiple linear regression analysis have shown that the entrepreneurship education has a significantly positive influence on the organizational commitment among the high-school teachers in South Sumatra. The moderating test has proved that the school's culture strengthens the entrepreneurship education towards the organizational commitment of high-school teachers in South Sumatra.

The results have shown that entrepreneurship education is significantly correlated with the school's culture and organizational commitment among high-school teachers in South Sumatra. Overall, this research has achieved the objectives to contribute to the existing body of knowledge on education. In addition, this study has suggested that the appropriate school's culture should be implemented in order to increase effective communication between the leaders, teachers, and other staff members in schools. The trust among them should also be strengthened in order to achieve the target together and solve the problems so that the school's objectives can be achieved.

In light of this study's findings, it is clear that entrepreneurship education plays a significant role in the organizational commitment of schools, especially high schools in South Sumatra.

\section{CONCLUSION}

This study was purposely conducted in order to examine the effect of entrepreneurship education towards a school's culture and organizational commitment among high schools in South Sumatra. The findings have shown that entrepreneurship education plays an important role in influencing the school's culture and organizational commitment. The teachers who displayed entrepreneurial skills are able to have a positive impact on their schools and surroundings; therefore, they can influence strong commitment and increase the school's performance.

In summary, this study has empirically proven the relationship between entrepreneurship education, school culture, and organizational commitment. Likewise, the result has indicated that the correlation among all variables could be the guideline and the necessity in determining the success and effectivity in school's performance. 


\subsection{Theoretical and Practical Implications}

Theoretically, this study expanded the resource-based view theory on the relationship between entrepreneurship education, school culture, and organizational commitment. In addition, this study has contributed to entrepreneurship education and its influence on school culture and organizational commitment. Likewise, this study's findings could expand another theory related to entrepreneurship education and organizational commitment as found by Hakimian et al. (2016).

Practically, the findings have contributed to the education system and the teachers in Indonesia. It can be seen that the teachers who implement their creativity in their problem-solving activity tend to be committed to their schools. Generally, this study affected the success of schools in achieving their vision and missions in the future.

\subsection{Limitations and future research}

This study focused on the cross-sectional study of the relationship among entrepreneurship education, school culture, and organizational commitment. Yet, the study could be expanded into a longitudinal study by comparing the elements under study before and after the implementation of organizational culture in schools' environment. Moreover, this study was limited to the context of South Sumatra, whereas a greater impact could be achieved by expanding the study throughout Indonesia or even Asia.

\section{References}

Acs, Z. J., Desai, S., \& Hessels, J. (2008). Entrepreneurship, economic development and institutions. Small business economics, 31(3), 219-234.

Brown, G. (2003) Speech by the Chancellor, Gordon Brown, to the 2003, Labour Party Conference, Bournemouth, 29 September.

Chughtai, A. A. (2013). Linking affective commitment to supervisor to work outcomes. Journal of Managerial Psychology, 28(6), 606-627.

Farrukh, M., Chong, W. Y., Mansori, S., \& Ravan Ramzani, S. (2017). Intrapreneurial behaviour: the role of organizational commitment. World Journal of Entrepreneurship, Management and Sustainable Development, 13(3), 243-256.

Fayolle, A., \& Gailly, B. (2015). The impact of entrepreneurship education on entrepreneurial attitudes and intention: Hysteresis and persistence. Journal of small business management, 53(1), 75-93.

Hakimian, F., Mohd, H. F., \& Ismail, N. I. (2016). Importance of Commitment in Encouraging Employees' Innovative Behaviour Introduction. Asia-Pacific Journal of Business Administration, $8(1)$.

Hansemark, O.C. (1998). The effects of an entrepreneurship programme on need for achievement and 
locus of control of reinforcement. International Journal of Entrepreneurial Behavior \& Research, 4(1), 28-50.

Honig, B. (2004). Entrepreneurship education: toward a model of contingency-based business planning. Academy of Management Learning \& Education, 3(3), 258-273.

Klinger, B., \& Schündeln, M. (2011). Can entrepreneurial activity be taught? Quasi-experimental evidence from Central America. World Development, 39(9), 1592-1610.

Kwiek, M. (2012). Universities, regional development and economic competitiveness: The Polish case, in Pinheiro, R., Benneworth, P. and Jones, G.A. (Ed.), Universities and Regional Development: A Critical Assessment of Tensions and Contradictions, Routledge, New York, pp. 69-85.

Lipton, M. (1962). Balanced and unbalanced growth in underdeveloped countries. The Economic Journal, 72(287), 641-657.

Lorz, M., Müller, S., \& Volery, T. (2011), Entrepreneurship education: a meta-analysis of impact studies and applied methodologies, conference paper, FGF G-Forum, Zurich.

Matlay, H., \& Farashah, A. D. (2013). The process of impact of entrepreneurship education and training on entrepreneurship perception and intention. Education+ Training.

Murphy, M., \& Dyrenfurth, M.J. (2012). Examining the role of the University in creating job. American Society for Engineering Education.

Nurhafifah. (2016). Pengaruh kepimpinan kepala sekolah, budaya sekolah, dan kinerja guru terhadap efektiviti sekolah di SMA Negeri Kabupaten Pringsewu. (Tesis PhD). Universitas Lampung.

Okereke, L. C., \& Okorafor, S. N. (2011). Entrepreneurship skills development for Millennium Development Goals (MGDs) in business education. Business Education Journal, 1(11), 83-88.

Ozag, D. (2006). The relationship between the trust, hope, and normative and continuance commitment of merger survivors. Journal of Management Development, 25(9), 870- 883. https://doi.org/10.1108/02621710610692070

Packham, G., Jones, P., Miller, C., Pickernell, D., \& Thomas, B. (2010). Attitudes towards entrepreneurship education: a comparative analysis. Education+ Training, 52(8/9), 568-586.

Powell, A., Galvin, J., \& Piccoli, G. (2006). Antecedents to team member commitment from near and far: A comparison between collocated and virtual teams. Information Technology \& People, 19(4), 299-322. https://doi.org/10.1108/09593840610718018

Puni, A., Anlesinya, A., \& Korsorku, P. (2018). Entrepreneurial education, self-efficacy and intentions in Sub-Saharan Africa. African Journal of Economic and Management Studies, https://doi.org/10.1108/AJEMS-09-2017-0211

Saks, A. M., \& Ashforth, B. E. (2002). Is job search related to employment quality? It all depends on the fit. Journal of applied Psychology, 87(4), 646. 
Taatila, V.P. (2010). Learning entrepreneurship in higher education. Education+Training, 52(1), 48-61. Thompson, M., \& Heron, P. (2006). Relational quality and innovative performance in R\&D based science and technology firms. Human Resource Management Journal, 16(1), $28-47$. https://doi.org/10.1111/j.1748-8583.2006.00003.x

Vesper, K.H. (1985). Entrepreneurship education 1985. Babson College.

Wilson, F., Kickul, J., Marlino, D., Barbosa, S. D., \& Griffiths, M. D. (2009). An analysis of the role of gender and self-efficacy in developing female entrepreneurial interest and behavior. Journal of developmental Entrepreneurship, 14(02), 105-119.

Zamberi Ahmad, S. (2013). The need for inclusion of entrepreneurship education in Malaysia lower and higher learning institutions. Education+ Training, 55(2), 191-203 